\title{
Miten sääntelyä muuttamalla voitaisiin ohjata kalastusta enemmän taloudellista arvoa luovaan suuntaan?1
}

Eelis Paukku

\section{Abstract}

Fishing tourism is a growing industry in Finland, generating significantly more value than commercial fishing. Fishing tourism also generates more value to rural areas with fewer economic activities. The value generated by fishing could be increased through promoting fishing tourism. There is no national research on regulation harmful to fishing tourism in Finland. In this article, first, a literature review on value creation in fishing tourism and commercial fishing is presented. After that, the regulations affecting fishing tourism and commercial fishing from the perspective of promoting these industries in a sustainable way are compared. The findings of this study indicate that the current fishing permit system in Finland favours commercial fishing at the expense of fishing tourism. The other conclusion is that permit-based fishing tourism could be significantly promoted without giving up the regulatory goals. In some cases, value generated by fishing could be promoted by restricting commercial fishing. In conclusion, it can be stated that the current regulations restricting fishing tourism are overly strict in comparison to the regulations governing commercial fishing. Value generated by fishing tourism could be significantly increased by increasing officials' decision-making powers in granting fishing tourism permits.

Keywords: fishing tourism, theory of regulation, commercial fishing

\section{Johdanto}

Viime aikoina luontoon liittyvä matkailu ja sen mukana myös kalastusmatkailu ovat nousseet tärkeämpään osaan syrjäisten alueiden taloudessa (Kauppila \& Karjalainen, 2012). Luontomatkailu hyödyttää erityisesti sellaisia alueita, jotka eivät hyödy muusta matkailusta (Camară \& Munteanu, 2016). EU:n politiikassa kalastusmatkailu on ollut painopistealueena jo 1990-luvun

1 Tutkimus on osa Suomen Akatemian Strategisen tutkimisneuvoston rahoittamaa hanketta Sopeutuminen sinisen kasvun avaimena (n:o 312652). 
alusta lähtien (Padin, Lima, Pardellas \& Xulio, 2016), mutta Suomessa kalastusmatkailua ja sen roolia ei juuri huomioida sääntelyssä tai politiikassa. Kalaresurssit ovat rajallisia, ja siksi niiden jakaminen eri kalastuksen muotojen välillä ja niiden sisällä aiheuttaa erilaisia konflikteja. Kalastusmatkailu kilpailee resursseista erityisesti kaupallisen kalastuksen kanssa (Moksness ym., 2011). Kaikilla alueilla vapaa-ajankalastus ja kalastusmatkailu eivät kuitenkaan merkittävästi haittaa toisiaan (Tiitinen, 2007, s. 158-159).

Tämän artikkelin tarkoituksena on selvittää, miten nykyinen lainsäädäntö ja muu julkisen vallan asettama sääntely vaikuttavat eri kalastuksen muotoihin, miten kalastuksen eri muodot tuottavat taloudellista arvoa ja miten sääntelyä kehittämällä voitaisiin parantaa kalastusmatkailun edellytyksiä Suomessa. Tarkasteltavana on sekä sisävesillä että merialueilla tapahtuva kalastus. Kotitarvekalastuksen tai virkistyskalastuksen tuottama taloudellinen tai muu arvo ei ole mukana tarkastelussa, mutta niiden mahdollisia konflikteja kaupallisessa tarkoituksessa tapahtuvan kalastuksen kanssa käsitellään. Kotitarve- ja virkistyskalastuksella tarkoitetaan laissa käytännössä kaikkea muuta kuin kaupallisessa tarkoituksessa tapahtuvaa kalastusta (HE 192/2014 vp, s. 32). Kalastusmatkailun edistämistä vesiympäristöjen tilaa parantamalla ei tarkastella, koska vesielinkeinojen tukemisesta on tuoretta tutkimusta (Paukku, 2019). Myös valtiontuen rooli kalastusmatkailussa jää tarkastelun ulkopuolella, vaikka se onkin ollut keskeinen elinkeinon kehittämisessä (Tiitinen, 2007, s. 135-137).

Koska tutkimuksen kohteena on kalastukseen vaikuttava sääntely ja se, miten sääntely kohtelee eri kalastuksen muotoja, kalastuksen käsitteet määritellään pääasiassa lainsäädännön näkökulmasta. Kalastusmatkailun määrittelyssä huomioidaan kuitenkin myös sen määrittely alaa koskevassa kirjallisuudessa, koska kalastusmatkailua koskeva lainsäädäntö on kohtuullisen tuoretta eikä lainsäädännöllinen käsitteistö ole vielä kovin vakiintunutta.

Kaupallisella kalastuksella tarkoitetaan tässä tutkimuksessa kalastusta, jonka tarkoituksena on kalastus pääasiassa kalojen myyntitarkoituksessa. Termi johtuu lainsäädännöstä, tarkemmin sanottuna kalastuslain (379/2015) 4 \$:n kohdasta 17. Termiä ei pidä sekoittaa ilmaisuun kaupallisessa tarkoituksessa tapahtuva kalastus, jolla viitataan sekä kaupalliseen kalastukseen että kalastusmatkailuun, kun tarkoituksena on erottaa ne kotitarve-ja virkistyskalastuksesta. Kalastusmatkailulla on yleensä tarkoitettu matkailua, jossa kalastus on pääasiallinen syy matkalle lähtemisessä eikä osa muita aktiviteetteja (Hänninen \& Tonder, 2001). Keskeinen ero kalastusmatkailun ja kaupallisen kalastuksen välillä on se, onko tavoitteena kalan ravintokäyttö vai kalastukseen ja vesiluontoon liittyvät elämykset. Taloudellisen arvon tuottamisella tarkoitetaan sitä, miten elinkeino tuottaa rahallista hyötyä elinkeinonharjoittajille ja ympäröivälle yhteiskunnalle.

Tutkimus on pääasiassa oikeustieteellinen, vaikka siinä on käytetty liiketaloustieteille tyypillisiä menetelmiä. Aluksi perehdytään ilmiöön ja sen suomalaiseen kontekstiin: kirjallisuuskatsauksen pohjalta tarkastellaan kaupallista kalastusta ja kalastusmatkailua liiketoimintana sekä näiden tuottamaa taloudellista arvoa. Tämän jälkeen tarkastellaan, miten sääntely kohtelee elinkeino- ja kalastusmatkailua. Kansallisen lainsäädännön lisäksi tarkastellaan Suomeen vaikuttavaa EU-sääntelyä. Tässä metodina toimii lainsäädännön sisältöä tarkasteleva käytännöllinen lainoppi eli lainoppi, jossa pyritään tulkitsemaan sääntelyn sisältöä (Aarnio, 2011, s. 104-105). Tukevana metodina toimii sääntelyteoria, joka tarkastelee lainsäädännön vaikutuk- 
sia toimijoiden päätöksentekoon (Määttä, 2016). Tarkemmin ilmaistuna käytetty teoria on normatiivinen sääntelyteoria, jossa tarkastellaan sitä, millainen sääntely auttaisi tietyn tavoitteen saavuttamisessa (Määttä, 2002, s. 133-134). Artikkelin keskusteluosassa tuloksia verrataan aikaisempaan kirjallisuuteen. Lopuksi esitetään johtopäätökset: vastataan tutkimuskysymyksiin sekä esitetään keinoja ja suosituksia kalastusmatkailun kehittämiseen sääntelyllä.

\section{Taloudellinen arvo ja kalavarojen kestävä käyttö}

Kalastusta tutkivan luonnonvarataloustieteen lähtökohta on, että kalavaroja hyödyntäminen on tehokkainta korkeimmalla kestävän hyödyntämisen tasolla (Conrad, 2011, s. 32-59). Tämä on myös Suomen ja EU:n kalastuspolitiikan lähtökohta. Tästä huolimatta Suomessa kalastetaan useita kalalajeja yli kestävän enimmäistason (Erkinaro ym., 2018). Kalavarojen kestävän käytön ylittyessä kaikki menettävät kalasaalista, koska kalakannat eivät uusiudu samaa vauhtia kuin niitä kalastetaan. Näin elinkeinon harjoittamisen mahdollisuudet tulevaisuudessa heikkenevät. Kalakantoja, erityisesti vaelluskaloja, suojataan tyypillisesti kalastuksen ajallisilla rajoituksilla (Conrad, 2011, s. 49). Suomessakin on käytössä tällaisia rajoituksia (Valtioneuvoston asetus kalastuksesta (1360/2015) $1 \$$ kalakantojen ajallisista rauhoituksista). Yleisin menetelmä kalastuksen kestävyyden sääntelyyn on ns. TAC-menetelmä (total allowable catch), jolla rajoitetaan kokonaissaaliin määrää (Conrad, 2011, s. 50). Myös EU:n yhteinen kalastuspolitiikka perustuu tähän menetelmään: kalakantojen kestävän hyödyntämisen taso määritellään alueittain, minkä jälkeen kiintiöt jaetaan jäsenvaltioille, jotka voivat jakaa ne kalastajille (Neuvoston asetus yhteisestä kalastuspolitiikasta). Menetelmä on kalakanta- ja vesialuekohtainen, mutta se kattaa ainoastaan merivedet. Jäsenvaltioiden sisävesillä noudatetaan kunkin jäsenvaltion omaa kalastuspolitiikkaa (Neuvoston asetus yhteisestä kalastuspolitiikasta, artikla 1, osa VIII ja osa X).

Kaupallista kalastusta harjoitetaan sekä teollisessa mittakaavassa että pienimuotoisesti. Kaupallisessa kalastuksessa lopullinen maksaja on tyypillisesti kalaa ravinnokseen käyttävä taho. Tuotteet jaetaan yleensä ns. bulkkikalaan eli suuren tuotantomäärien halpoihin kalatuotteisiin sekä korkeamman arvon tuoreisiin kaloihin (Hamilton-Hart \& Stringer, 2016). Koska taloudellinen arvo kaupallisessa kalastuksessa riippuu kalan määrästä, kalakantoja pyritään kalastamaan niin suuria määriä kuin sääntelyn ja ympäristön puitteissa on mahdollista (Kasulo \& Perrings, 2006). Kalastuksesta pyritään tekemään mahdollisimman tehokasta eli kustannuksia pyritään minimoimaan saalistettua kalaan kohden (Hamilton-Hart \& Stringer, 2016). Lisäksi kalastuksen tulee olla ympäristön kannalta kestävää, koska muutoin menetetään kaupallisen kalastuksen pitkän aikavälin mahdollisuudet (Kasulo \& Perrings, 2006).

Kaupallisessa kalastuksessa merkittävin osa luodusta arvosta syntyy kalastajien tekemästä työstä, jonka lopputuloksena on jalostuskelpoista saaliskalaa (Naji, Araba, Benabdellah \& Dehhaoui, 2015). Myös työpaikoista suurin osa liittyy itse kalastustoimintaan; jalostuksen ja jälleenkäsittelyn työllistävyys tuotettua kalatonnia kohden on huomattavasti pienempi (Naji ym., 2015). Taloudellista arvoa pystytään kaupallisessa kalastuksessa lisäämään tehostamalla kalastusta ja kalan käsittelyketjua sekä kalastamalla ympäristön kannalta kestävämmällä tavalla, koska tämä mahdollistaa kalastuksen myös tulevaisuudessa. Tällöin ei kuitenkaan voida luoda lisää 
arvoa jo kalastettua ravintokalaa kohden juuri lainkaan, vaan arvo syntyy kalan käsittelyketjun tehostamisesta (Hamilton-Hart \& Stringer, 2016). Kalan käsittelyketju ja erityisesti jälleenmyynti keräävätkin usein merkittävimmän osan kalastuksen tuotoista (Naji ym., 2015). Kaupallisen kalastuksen tuotteet toimivat ravinnonlähteinä muiden ravinnonlähteiden joukossa ja niiden kanssa kilpaillen, mikä rajoittaa mahdollisuuksia tuottaa lisää taloudellista arvoa kalaa kohden. Suomessa merkittävä osa ammattikalastuksen kalansaaliista päätyy eläinten rehuksi (Luonnonvarakeskus, 2018). Kalan loppukäyttö vaikuttaa myös siitä saatavaan arvoon, vaikka eri kalalajien käytettävyys eri loppukäyttötarkoituksiin vaihtelee merkittävästi, eikä kalantuottaja pysty juuri vaikuttamaan näihin asioihin.

Kalastusmatkailun tuottamaa hyötyä on tutkittu melko laajasti eri puolilla maailmaa. Matkailun tuottamat taloudelliset hyödyt jaotellaan tyypillisesti suoriin ja epäsuoriin (Kauppila \& Karjalainen, 2012). Suoria hyötyjä tuo matkailijoiden rahankäyttö erilaisiin palveluihin ja tavaroihin, kuten majoitukseen, ateriointiin ja vähittäiskaupan tuotteisiin. Epäsuoriksi hyödyiksi taas on katsottu hyödykkeiden toimittaminen niille yrittäjille, jotka hyötyvät suoranaisesti matkailusta. Kalastusmatkailulla on katsottu olevan myös muita kuin taloudellisia hyötyjä. Tällaisia ovat muun muassa sosioekonomiset vaikutukset elinkeinorakenteen monipuolistuessa sekä kalastukseen liittyvän kulttuurin säilyttäminen ja sen tukeminen (Padín, Lima \& Pardellas, 2016). Kalastusmatkailu voi osaltaan edistää myös alueen luontoarvojen huomioimista, koska esimerkiksi veden laatu vaikuttaa keskeisesti siihen, kuinka arvokkaana asiakkaat pitävät matkailukokemusta (Lee, 2016, s. 788).

Kalastusmatkailun tuottama rahallinen arvo kalaa kohden on olennaisesti suurempi kuin kaupallisessa kalastuksessa. On arvioitu, että kalastusmatkailussa pyydystetyn kalan tuottama arvo on kymmenen kertaa suurempi kuin kaupallisessa kalastuksessa (Cap Gemini Ernst \& Young, 2003). Myös ympäröivälle alueelle kalastusmatkailu tuottaa taloudellista arvoa merkittävästi enemmän kuin kaupallinen kalastus. Arvoa syntyy kalastusmatkailuyritysten lisäksi useille muillekin matkailu- ja palvelutoimialojen yrityksille. (Kauppila \& Karjalainen, 2012.) Esimerkiksi Tornionjoella yhden kalastusmatkailussa kalastetun lohen arvo on noin 1320 euroa (Maa- ja metsätalousministeriö, 2018, s. 53). Kalastusmatkailusta aiheutuu myös kustannuksia ympäröivälle yhteiskunnalle. Kalastusmatkailu vaatii tuekseen monimutkaisempaa ja siten kalliimpaa infrastruktuuria kuin kaupallinen matkailu - toisaalta infrastruktuurin vaatimat investoinnit saattavat virkistää paikallista taloutta (Camară \& Munteanu, 2016, s. 201). Kalastusmatkailu voi lisätä työpaikkoja alueella. Kalastukseen osallistuvien tahojen lisäksi työpaikkoja syntyy etenkin ravintolapalveluihin ja kuljetukseen, mutta pienemmässä määrin muihinkin palveluihin (Gurung \& Thing, 2016, s. 56). Kalastusmatkailun oheispalvelut tuottavat paikkakunnalle jäävää verotuloa, ja näin kalastusmatkailu hyödyttää paikkakuntaa ja aluetta enemmän kuin kaupallinen kalastus, jossa merkittävä osa rahasta valuu vähittäismyyntiin ja jalostukseen (Kauppila \& Karjalainen, 2012; Naji ym., 2015).

Kalastusmatkailu voi aiheuttaa ympäristöhaittoja. Eräillä alueilla kalastusmatkailu on johtanut joidenkin kalakantojen kestämättömään kalastukseen, minkä vuoksi kalastusmatkailua on säädelty voimakkaasti erilaisilla kiintiöillä ja rajoituksilla (Moksness ym., 2011). Kannattava kalastusmatkailu edellyttää riittävän suurien vesialueiden käyttöä sekä riittävän suuria mat- 
kailijaryhmiä, mikä vaikuttaa väistämättä jollain tavalla ympäristön tilaan sekä muiden luonnonvarojen käyttäjien oikeuksiin (HE 192/2014 vp, s. 41). Haitallisia vaikutuksia on onnistuttu rajoittamaan esimerkiksi kohdistamalla matkailua itse kalastuksen sijaan muuhun kaloihin liittyvään toimintaan, kuten kalojen katseluun (Vianna, Meekan, Pannell, Marsh \& Meeuwig, 2012). Suomessa kalasaalis on kuitenkin usein olennainen osa kalastusmatkaa - joskin saaliin merkitys vaihtelee kalastajatyypeittäin (Markuksela, 2009, s. 192-193). Luontoarvoiltaan arvokas sijainti vaikuttaisi joka tapauksessa olevan tärkeää kalastusmatkailuyrityksille (Tiitinen, 2007, s. 126-127). Kokeneempien kalastajien on todettu arvostavan ympäristöarvoja enemmän kuin kokemattomampien (Soppela, 2009, s. 188). Ympäristöarvot ovat tärkeitä useille muillekin matkailijaryhmille, eivät vain kalastusmatkailijoille (Vespestad, Lindberg \& Mossberg, 2019). Kestävyyteen on kalastusmatkailussa kiinnitetty erityistä huomiota (Camară \& Munteanu, 2016). Koska kalastusmatkailu tuottaa hyötyjä paikallisyhteisöille, se edistää myös mahdollisuuksia taloudellisesti ja sosiaalisesti kestävään kehitykseen (Gurung \& Thing, 2016, s. 58).

Yksi kalastettu kala luo siis kalastusmatkailussa huomattavasti enemmän taloudellista arvoa kuin muissa kalastuksen muodoissa. Kalastettua kalaa kohden käytetään enemmän rahaa sekä kalastukseen että alueen tarjoamiin muihin palveluihin. Toisaalta kalastusmatkailu ei mahdollista samalla tavoin ravinnontarpeen tyydyttämistä kuin kaupallinen kalastus, joka tuottaa hyötyä kalastetun kalan kalastamisella ja jalostamisella ravinnoksi ihmisille tai eläimille. Kalastusmatkailussa merkittävä rahankäytön kohde ovat paikalliset oheispalvelut, erityisesti ravintola- ja kuljetuspalvelut. Nämä lisäävät alueellisia työpaikkoja ja verotuloja. Matkailijoiden käyttämät palvelut ovat tyypillisesti paikallisia. Voidaan siis kiistatta sanoa, että kalastusmatkailu tuottaa enemmän arvoa paikallistaloudelle kalastettua kalaa kohden kuin muut kalastuksen muodot.

Jos kaupallisessa tarkoituksessa tapahtuvien kalastuksen muotojen taloudellista arvoa ja erityisesti paikallista taloudellista arvoa haluttaisiin kohdentaa ravinnontuotannon sijaan palvelukulutukseen ja lisätä taloudellista arvoa kalastettua kalaa kohden, olisi perusteltua priorisoida sääntelyssä kalastusmatkailua. Toisaalta nykytiedon varassa ei voida olettaa, että kaikki saatavilla olevat resurssit voitaisiin käyttää kalastusmatkailuun. Kaupallisella kalastuksella onkin tulevaisuudessa yhä merkittävä rooli elinkeinona, eikä sen toimintaa tulisi haitata tarpeettomasti, jotta kalastuksen kokonaisarvo ei laskisi kalakantojen jäädessä hyödyntämättä kestävällä tavalla. Kestävyys on olennaista kalastuselinkeinoja kehitettäessä, koska muutoin elinkeinoa ei voida harjoittaa pitkäaikaisesti kalakantojen huvetessa tai ympäristön tilan huonontuessa. Ympäristön tila on erityisen tärkeää kalastusmatkailulle, koska luonnon virkistysarvolla on siinä merkittävä rooli. Tämä tosin vaihtelee kalastajaryhmittäin; osa painottaa enemmän kalasaalista, osa rauhallisuutta (Markuksela, 2009, s. 192-193). Ympäristön tilan merkitys voidaan välillisesti huomioida politiikkatoimissa ja sääntelyssä.

Kalastusmatkailu ja kaupallinen kalastus eivät ole täysin toisilleen vastakkaisia elinkeinoja. Usein ne eivät häiritse toisiaan lainkaan (HE 192/2014 vp, s. 7-8). Vaelluskalojen kaupallinen kalastus on kuitenkin jo pitkään häirinnyt kalastusmatkailua vähentämällä kalasaaliita ja pienentämällä saaliskalojen kokoa (Salmi \& Salmi, 2010). Useiden kalakantojen uhanalaisuus ja kalastussääntelyn tehottomuus haittaavat kaikkea kalastusta. Kaupallinen kalastus merellä 
aiheuttaa kuormitusta useille kalakannoille jopa yli kestävän enimmäistason (Oksanen, 2011, s. 262). Kalastusmatkailun ei ole katsottu aiheuttavan juurikaan ongelmia kalakannoille Suomessa (HE 135/2011 vp, s. 3). Joskus kalastusmatkailulla voidaan täydentää kaupalliseen kalastukseen perustuvaa elinkeinoa (Salmi, 2015).

Kaupallinen kalastus ja kalastusmatkailu käyttävät osittain samaa maa- ja vesi-infrastruktuuria (Jacek \& Matczak, 2018, s. 3). Kalastusmatkailun palvelut vaativat kuitenkin erillistä infrastruktuuria, ja kalastusmatkailussa yrityksen sijainnilla on huomattavasti suurempi merkitys kuin kaupallisessa kalastuksessa (Tiitinen, 2007, s. 127-128). Kalastusmatkailu voi lisätä aiemmin kaupallista kalastusta harjoittaneiden henkilöiden tuloja, mutta toisaalta samat henkilöt voivat harjoittaa molempia kalastuksen muotoja (Gurung \& Thing, 2016, s. 58). Sääntely voi kehittää molempia elinkeinoja yhdessä, mutta viime kädessä sääntely joutuu asettamaan elinkeinot vastakkain, koska ne käyttävät samoja resursseja.

\section{Kalastukseen vaikuttava sääntely}

\section{EU-sääntely}

Kalastukseen vaikuttava sääntely on osin kansallista, osin eurooppalaista. EU:n yksinomaiseen toimivaltaan kuuluu sääntely koskien sellaisia kalakantoja, jotka liikkuvat jäsenvaltioiden vesirajojen sisällä vapaasti. Muutoin kalastus on määritelty maatalouden tavoin jaetun toimivallan piiriin kuuluvaksi (Oksanen, 2011, s. 259). EU-säännöksillä säännellään erityisesti yhteistä kalastuspolitiikkaa, jonka soveltamisalaan on määritelty kuuluvan meren elollisten luonnonvarojen säilyttäminen sekä niitä hyödyntävän kalastuksen hoito. Käytännössä kalastuspolitiikassa ja siten myös sääntelyssä keskeistä on kalastuksen kestävyys eli kalastuksen rajoittaminen kestävään määrään (Neuvoston asetus yhteisestä kalastuspolitiikasta, perusteluiden kohdat 2-12). Tämän periaatteen taustalla on se, että kalastuspolitiikkaa muutettaessa 2000-luvun ensimmäisen vuosikymmenen lopussa suurin osa kalakannoista EU:ssa kärsi liikakalastuksessa eli oli ekologisesti kestämättömällä tasolla (Oksanen, 2011, s. 262). EU-asetus yhteisestä kalastuspolitiikasta muodostaa sääntelypohjan toimenpiteille, joilla kalastusta rajoitetaan kalakantojen säilyttämiseksi. Nämä rajoitukset koskevat ainoastaan kaupallista kalastusta, eli virkistyskalastus ja kalastusmatkailu jäävät rajoitusten soveltamisalan ulkopuolelle. (Oksanen, 2011, s. 256.)

Kalastuspolitiikasta annetun asetuksen 6-7 artiklan perusteella neuvosto antaa täytäntöönpanoasetuksen, jossa määritellään tarkemmin rajoituksia kalastukselle Euroopan unionin alueella. Täytäntöönpanoasetuksessa määritellään suurimmat sallitut saalit (total allowable catch) eli TAC:t sekä niiden jako jäsenvaltioittain ja alueittain (Neuvoston kalakanta-asetus, perusteluiden kohdat 3-5). Kalastukseen Itämerellä on määritetty omat maakohtaiset kiintiöt. Asetus koskee silakkaa, turskaa, punakampelaa, lohta ja kilohailia (Neuvoston kalakanta-asetuksen liite). Näistä erityisesti lohi on ollut kalastusmatkailussa arvokas laji koko kalastusmatkailun historian ajan (Tiitinen, 2007, s. 126-127). Siksi lohen kalastuskiintiöiden jakaminen on aiheuttanut ristiriitoja (Stensland, 2010).

Yhteinen kalastuspolitiikka ei sääntele kalastusta sisävesillä samalla tavalla kuin merialueilla, koska asetuksen soveltamisala on kalakantojen säilyttämisen osalta rajattu kalastukseen 
merillä. Makeisiin vesiin asetusta sovelletaan ainoastaan markkina- ja rahoitustoimenpiteiden osalta (Neuvoston asetus yhteisestä kalastuspolitiikasta, artikla 1, osa VIII ja osa X). Suomessa kalastusmatkailua on enemmän jokialueilla ja muilla sisävesillä kuin merialueilla (Salmi \& Salmi, 2010), mutta kalastusmatkailua on myös merialueilla (HE 192/2014 vp, s. 41). Sisävesipainotteisuuden takia meillä kalastusmatkailua koskee lähinnä kansallinen sääntely. Sisävesillä tapahtuva matkailu- ja virkistyskalastus eivät nykytiedon valossa ole uhka biodiversiteetille tai kalakannoille, vaan näihin liittyviä ongelmia aiheuttaa kaupallinen kalastus merellä (Salmi \& Salmi, 2010).

Vaikka Euroopan unionin yhteinen kalastuspolitiikka ei suoraan koske kalastusmatkailua, sillä voi olla tiettyjä epäsuoria vaikutuksia. Aikaisemmin matkailu- ja virkistyskalastuksen suurimpana uhkana on ollut liikakalastus merellä, joka on vähentänyt vaelluskalojen kalastusmahdollisuuksia jokialueilla (Salmi \& Salmi, 2010). Lohen kalastuksen voimakas vähentyminen merialueilla ja rajoittuminen rannikkoalueisiin viime vuosina saattaa lisätä kalastusmatkailun mahdollisuuksia jokialueilla (Erkinaro ym., 2018, s. 26-28). Lohen merkitys meri- ja rannikkoalueiden kalastusmatkailussa on perinteisesti ollut hyvin vähäinen (Tiitinen, 2007, s. 127). Sisävesillä kalastetaan lohen lisäksi muikkua, haukea ja kuhaa (Setälä ym., 2017). Rannikoilla myös ahven on arvokas saaliskala (Tiitinen, 2007 s. 127-128). Muikun kalastus on melko kestävällä tasolla, joskin muikkujen koko vaihtelee melko suuresti (Luonnonvarakeskus, 2019).

Kalastusmatkailu tarvitsee tiettyjä lupia, joita myönnettäessä arvioidaan kalakantojen kestävää hyödyntämistä. Tämä saattaa johtaa kilpailuun resursseista kaupallisen kalastuksen kanssa merialueilla, joissa EU:n kalastuskiintiöt asettavat rajat kaupalliselle kalastukselle, mutta kansalliset viranomaiset arvioivat kalakantojen kestävyyttä vielä näiden rajojen puitteissa (Laki Euroopan unionin yhteisen kalastuspolitiikan kansallisesta täytäntöönpanosta (1048/2016) 5 §). Koska EU:n kaupalliselle kalastukselle myöntämät enimmäiskiintiöt ovat usein kestävän kalastuksen äärirajoilla, kansalliset viranomaiset joutuvat arvioimaan, voidaanko kaikki kalastuskiintiöt jakaa niin, että kalakantojen kestävyys säilyy (Oksanen, 2011, s. 262). Tämä saattaa aiheuttaa vastakkainasettelua kaupallisen kalastuksen, virkistyskalastuksen ja kalastusmatkailun välillä. Historiallisesti sääntelyllä on pyritty mahdollistamaan virkistyskalastus, mikä on käytännössä tarkoittanut kaupallisen kalastuksen rajoittamista virkistyskalastuksen kustannuksella (Salmi \& Salmi, 2010).

EU:n kalastuspolitiikka ja sen kansallinen täytäntöönpano vaikuttavat kalavarojen kestävän hyödyntämisen mahdollisuuksiin ja sitä kautta kaikkien kalastuselinkeinojen, myös matkailukalastuksen, harjoittamisen mahdollisuuksiin. Unionin yhteisestä kalastuspolitiikasta ja sen kansallisesta täytäntöönpanosta huolimatta useat merialueilla kalastettavat kalat ovat nykyisin kestävän kalastuksen äärirajoilla tai jopa ylittävät sen, mikä saattaa olla uhka sekä rannikkoalueilla tapahtuvalle että vaelluskaloihin liittyvälle kalastusmatkailulle. (Erkinaro ym., 2018.)

\section{Kalastuksen kansallinen sääntely}

Kalastuksen yleislaki on kalastuslaki. Kalastuslain 3 \$:n mukaan sitä sovelletaan kaikkeen kalastukseen, jos EU-sääntelystä tai sen täytäntöönpanemiseksi annetusta kansallisesta sääntelystä ei johdu muuta. Edellä käsitellyn EU-sääntelyn lisäksi kalastuslain soveltamisalaa rajoittaa laki Euroopan unionin yhteisen kalastuspolitiikan kansallisesta täytäntöönpanosta (1048/2016). 
Kalastuslakia tarkentaa Valtioneuvoston asetus kalastuksesta (1360/2015), jossa säädetään tarkemmin kaikkia kalastuksen muotoja eli kaupallista ja vapaa-ajan kalastusta sekä kalastusmatkailua koskevista rajoituksista. Ne liittyvät muun muassa kalojen pyyntimittoihin, rauhoitusaikoihin, vaelluskalojen pyyntiin sekä pyyntivälineisiin. Nämä rajoitukset vaikuttavat nimellisesti samalla tavalla kaikkiin kalastustapoihin, mutta kalastustapojen erilaisen luonteen takia rajoitukset voivat käytännössä kohdistua eri tavalla. Kalastusmatkailua harjoitetaan tyypillisesti ns. yleiskalastusoikeuksien tavoin, minkä vuoksi erilaiset verkkorajoitukset, joista asetuksessa säädetään laajasti, eivät juuri vaikuta kalastusmatkailuun (HE 135/2011 vp, s. 3).

Kalastuslain lähtökohtana on sen 5 \$:ssä säädetty rajoitus, että vain vesialueen omistaja tai tältä kalastuslain 11 \$:n nojalla kalastusoikeuden vuokrannut saa kalastaa vesialueella, jos kalastuslaki ei muuta määrää. Kalastuslain 7 \$:ssä säädetään ns. yleiskalastusoikeuksista eli jokaisen oikeudesta kalastaa onkien, pilkkien ja vieheellä (HE 192/2014 vp). Tämä poikkeus ei kuitenkaan koske järjestettyjä tilaisuuksia, jotka tarkoittavat myös kalastusmatkailua. Tämä todetaan myös hallituksen esityksessä, jossa todetaan oikeustilan olevan se, että kalastusmatkailua ei voida harjoittaa yleiskalastusoikeuksien nojalla (HE 192/2014 vp). Tulkinta perustuu korkeimman oikeuden ratkaisuun KKO 2006:70, jossa todettiin, että elinkeinotoiminnassa järjestetty kolmen hengen kalastusmatka ei ollut yleiskalastusoikeuden piiriin kuuluvaa toimintaa, vaan se vaati kalastusoikeuden haltijan luvan. Ratkaisun katsottiin olevan ristiriidassa silloisen kalastuslain (286/1982) 1 \$:ssä mainitun tavoitteen kanssa, jossa todettiin seuraavasti:"kalastusta harjoitettaessa on pyrittävä vesialueiden mahdollisimman suureen pysyvään tuottavuuteen" (Mylly, 2007, s. 10). Tämä korkeimman oikeuden tulkinta johti myöhemmin kalastuslain muuttamiseen siten, että kalastusmatkailu helpottuisi (HE 135/2011 vp, s. 1). Koska kalastusoikeudet jakautuvat usealle eri taholle, lupien saaminen kalastusoikeuksien haltijoilta on erittäin vaikeaa. Kun huomioidaan vielä kalastuksen liikkuva luonne ja kalavarojen liikkuminen melko vapaasti, yksittäisen pienen alueen kalastusoikeuden puuttuminen voi estää hyvinkin laajan alueen käyttämisen kalastusmatkailuun tai kaupalliseen kalastukseen (HE 192/2014, vp s. 38).

Merikalastuksen salliva $8 \$$ mahdollistaa kalastusmatkailun, koska pykälässä sallitaan vapaa-ajan kalastus. Hallituksen esityksen perusteella kotitarve- ja virkistyskalastus kattaa myös kalastusmatkailun, koska esityksen sanamuodon mukaisesti "käytännössä vapaa-ajan kalastusta olisi siten kaikki muu kuin kaupallinen kalastus" (HE 192/2014 vp, s. 32). Tämä vastaa myös kirjallisuudessa tehtyä luokittelua, jossa vapaa-ajan kalastus jaetaan kotitarve- ja virkistyskalastukseen sekä alaryhmiin, kuten urheilukalastukseen ja kalastusmatkailuun (Soppela, 2009, s. 23-25). Kaupallinen kalastus taas määritellään kalastuslain 4 \$:n kohdassa 17 kalastukseksi, jossa kalaa pyydetään myyntitarkoituksessa. Kalastusmatkailu ei täytä tätä edellytystä, koska kalastajat ottavat kalat tyypillisesti muuhun kuin myyntikäyttöön. Tämän vuoksi kalastusmatkailussa harjoitettu kalastus olisi lähinnä vapaa-ajan kalastukseen kuuluvaa virkistyskalastusta, joka määritellään hallituksen esityksessä seuraavasti: "Virkistyskalastuksena pidettäisiin kalastusta, jonka saalis käytetään kalastajan taloudessa mutta sillä ei ole toimeentulon kannalta merkitystä" (HE 192/2014 vp, s. 32). Kalastusmatkailua rajoittaa yleisen kalastusoikeuden rajoituksen lisäksi lähinnä se, että joissakin kalastuslain kohdissa "järjestetyt tilaisuudet" on rajattu poikkeusten soveltamisalojen ulkopuolelle. 


\section{Kalastus viranomaisluvalla}

Kalastusmatkailusta säädetään erikseen kalastuslain 18 \$:ssä. ELY voi myöntää luvan kalastusmatkailutilaisuuksiin toimialueellaan, jos tilaisuuksiin osallistuu enintään kuusi ihmistä ja jos harjoitettu kalastus rajautuu yleiskalastusoikeuksien piiriin. Tämä kattaa siis myös kalastuksen yksityisillä vesillä. Kuutta henkeä suurempiin tilaisuuksiin tarvitaan vesialueen omistajan tai kalastusoikeuden haltijan lupa. Lupaa myönnettäessä keskeisin kriteeri on kalakantojen kestävyyden turvaaminen; se on pykälän mukaan otettava huomioon sekä lupaa määrättäessä että sen ehtoja määriteltäessä. Lupaehdoissa on lain mukaan asetettava sellaisia rajoituksia, joilla turvataan kalakantojen kestävyys. Käytännössä lupa kalastusoikeuden haltijalta tai viranomaiselta on tärkeä kalastusmatkailuyritysten toiminnalle, koska hyvin pieni osa yrityksistä harjoittaa toimintaansa siten, että toiminta katsottaisiin yleiskalastusoikeuksien piiriin kuuluvaksi. Tällaisia yrityksiä ovat lähinnä majoitustoimintaan ja kaluston vuokraamiseen keskittyneet yritykset. (Tiitinen, 2007, s. 128-129.)

Muutettaessa kalastuslakia pyrittiin edistämään kalastusmatkailua elinkeinona, koska lupien saaminen oli havaittu usein vaikeaksi. Tämä korostui erityisesti merialueilla, joissa omistus on hyvin pirstaleista, mutta myös kalastusoikeuksien haltijoiden ennakkoluulojen katsottiin vaikeuttaneen lupien saamista (HE 135/2011 vp, s. 1-2). Toisaalta vesialueiden jakaantuminen osakaskuntiin on jossain määrin vähentänyt pirstaloitumista (Tiitinen, 2007, s. 142). Kalastusmatkailussa toiset alueet ovat luontoarvojensa ansiosta huomattavasti toisia arvokkaampia, mikä vähentää mahdollisuuksia sijoittaa toimintoja muille alueille ja sitä kautta lisää pirstaleisuudesta aiheutuvaa haittaa ja vaivaa (Markuksela, 2013, s. 228-230). Eri kalastusmatkailijatyypit myös suosivat erilaisia alueita ja palvelukeskittymiä, mikä lisää tarvetta voida järjestää kalastusmatkailua erilaisilla alueilla (Soppela, 2009, s. 91-93). Yritysasiakkaat ovat tärkeä kalastusmatkailun asiakasryhmä, ja yritysasiakkailla ei useinkaan ole aikaa matkustaa kaukana oleviin kohteisiin (Tiitinen, 2007, s. 128-129).

Vesialueen haltijalta tarvittavan luvan tulkittiin haittaavan kalastusmatkailua perusteetta korkeista transaktiokustannuksista ja ylihinnoittelusta johtuen (Mylly, 2007, s. 12). Lain muutoksella puututtiin nimenomaan näihin markkinahäiriöihin ja siten ainakin oletetusti tehostettiin markkinoiden toimintaa. Kalastusmatkailuyrityksissä merkittävä osa toiminnan epävarmuudesta liittyy vesialueiden käyttömahdollisuuksiin (Tiitinen, 2007, s. 141).

Myös kaupallista kalastusta sädelllään kalastuslaissa. Kaupallisella kalastuksella tarkoitetaan lain 4 \$:n kohdan 17 mukaan toimintaa, jossa kalaa pyydetään myyntitarkoituksessa tai jossa pyydetyt kalat tai osa niistä myydään. Kaupallisessa kalastuksessakin lähtökohtana on vesialueen omistajan yksinoikeus kalastaa alueellaan. Vesialueen omistaja voi luovuttaa tämän oikeuden myös toiselle. Poikkeuksena ovat valtion merialueet, joilla kalastusta rajoittavat ainoastaan kalastuskiintiöt. Valtion vesialueilla ja talousvyöhykkeellä kalastuksesta säädetään tarkemmin lain 8 §:ssä. Kaupalliseen kalastukseen sovelletaan lisäksi kalastusasetuksessa (Valtioneuvoston asetus kalastuksesta (1360/2015)) määriteltyjä kalastusrajoituksia, jotka koskevat muun muassa kalastusaikoja ja käytettäviä pyydyksiä. Kalastajat ovat pääosin tyytyväisiä rajoituksiin, koska ne perustuvat osin kalastusperinteisiin ja niissä huomioidaan kalastusmatkailun tarpeet (Soppela, 2009, s. 185-186). 
Kaupalliselle kalastukselle on säädetty myös samanlainen helpotus kalastusoikeuden hankkimiseen kuin kalastusmatkailulle. Tämä helpotus sisältyy kalastuslain 13 §:ään, joka sisältää mahdollisuuden hakea ja saada ELY-keskukselta lupa kaupalliseen kalastukseen tietyllä alueella enintään viiden vuoden ajaksi. Helpotuksen tavoitteena on parantaa kaupallisen kalastuksen toimintaedellytyksiä ja helpottaa kaupallisten kalastajien mahdollisuuksia harjoittaa elinkeinoaan sekä lisätä kotimaisen kalan tarjontaa niin kauppoihin kuin jalostustoimintaankin (HE 192/2014 vp, s. 38). Luvan saamiseksi neljän edellytyksen on täytyttävä:

1. Alue on määritelty käyttö- ja hoitosuunnitelmissa (joihin viitataan kalastuslain luvussa 4) kaupalliseen kalastukseen hyvin soveltuvaksi.

2. Kalakantojen tila mahdollistaa niiden hyödyntämisen kaupalliseen kalastukseen. Tässä huomioidaan yksi kalastuksen sääntelyn päätavoitteista EU:n ja kansallisella tasolla eli kalastuksen ekologinen kestävyys. (Kalastuslaki 1 \$; HE 192/2014 vp, s. 1; Oksanen, 2011, s. 281.)

3. Luvanhakija ei ole päässyt edes kalatalousalueen avustuksella sopimukseen vesialueen haltijan kanssa. Tämän edellytyksen tarkoitusta ei mainita laissa, mutta koska yhtenä lainsäädännön yleisenä tavoitteena on viranomaisten hallinnollisten kustannusten rajoittaminen (Oikeusministeriö, 2007, s. 28), kyseessä on todennäköisesti lupaviranomaisen resurssien säästämiseen liittyvä rajoitus. Lisäksi edellytyksen taustalla on luultavasti se, että lainmuutoksen tarkoituksena ei ollut muodostaa omistajan suostumukselle vaihtoehtoista vaan ainoastaan sitä tarvittaessa täydentävä järjestelmä (HE 192/2014 vp, s. 39).

4. Kaupallinen kalastus ei saa aiheuttaa merkittävää haittaa rannanomistajille tai alueen muulle käytölle. Vaikka haittaa ei tarkasti kuvata kalastuslain esitöissä, aiemmissa lainmuutoksissa vastaavilla haitoilla on tarkoitettu muun muassa rannanomistajille kalastuksesta aiheutuvaa häiriötä, kuten melua ja rauhallisuuden vähentymistä (HE 135/2011 vp, s. 4). Muulla käytöllä tarkoitetaan tässä tapauksessa mm. vesialueen omistajan lupaan perustuvaa kaupallista kalastusta (HE 192/2014 vp, s. 39).

Tätä poikkeusta säädettäessä painotettiin, että kalastusalueen haltijan omistusoikeutta ei rajoiteta, vaan alueen kalavarojen hyödyntäminen mahdollistetaan niin pitkälle, että se voidaan tehdä ekologisesti kestävällä tavalla kalastusoikeuden haltijan kalastusoikeutta rajoittamatta (PeVL 58/2014 vp - HE 192/2014, vp). Luvan myöntämisen ehdottomana esteenä on 13.3 \$:n mukaan se, että kalastus viranomaisluvalla heikentäisi kohtuuttomasti kalastusoikeuden haltijan mahdollisuutta hyödyntää kalastusoikeuttaan tai siitä aiheutuisi muuta merkittävää haittaa. Kalastusmatkailun vaikutuksia arvioitaessa on huomioitava se, että vapaa-ajankalastuksen, johon myös kalastusmatkailu kuuluu, kalastusmaksuilla rahoitetaan pitkälti kalakantojen hoito (Markuksela, 2009, s. 47).

Nykylainsäädännön valossa on epäselvää, miten viranomainen ratkaisisi lupa-asian, jos luvan hakijoissa samaan kalastusalueeseen olisi sekä kaupallisia kalastajia että kalastusmatkailutoimintaa harjoittavia yrityksiä eivätkä kalakannat riittäisi kaikkien toiminnan harjoittamiseen. Kalastuslaki ei säätele tällaisten toimintojen etusijajärjestyksestä; ainoastaan kaupallisten kalastajien hakemusten välisestä etusijajärjestyksestä säädetään lain 15 \$:ssä. Myöskään hallituksen esityksessä ei mainita kalastusmatkailun ja kaupallisen kalastuksen välistä konfliktinratkaisua. Luvan myöntämisen esteenä mainitaan esimerkkinä ainoastaan se, että lupa häi- 
ritsisi toisen kaupallisen kalastajan toimintaa (HE 192/2014 vp, s. 39). Toki kysymyksenasettelu on melko teoreettinen, koska nykyisellään kalastusmatkailun ei katsota vaikuttavan juurikaan kalakantoihin, ja tällaiset tilanteet olisivat siten melko harvinaisia (HE 135/2011 vp, s. 3; Salmi \& Salmi, 2010). Mahdollinen ristiriita voitaisiin melko helposti ratkaista $13 \$$ :n mukaisessa lupaharkinnassa säätämällä enimmäissaalis kaupalliselle kalastukselle, jolloin molempien lupaa hakeneiden tahojen tarpeet voitaisiin luultavasti tyydyttää.

Sekä kalastusmatkailuun että kaupalliseen kalastukseen vaikuttaa merkittävästi kalastuslain 36 \$. Pykälässä säädetään kalatalousalueen käyttö- ja hoitosuunnitelmasta, jonka yksi tavoite on kalataloudellisesti merkittävien alueiden sekä kaupalliseen kalastukseen ja kalastusmatkailutarkoitukseen hyvin soveltuvien alueiden määritys. Alueen määrittämistä kaupalliseen kalastukseen soveltuvaksi edellytetään suoraan kaupallisen kalastuksen viranomaisluvalla mahdollistavassa 13 \$:ssä. Kalastusmatkailun viranomaisluvalla mahdollistavassa 18 \$:ssä ei suoraan mainita käyttö- ja hoitosuunnitelmaa, mutta viranomaisen on otettava huomioon alueellinen kalakantojen tila, jota käsitellään myös kalataloussuunnitelmassa. Kalastussuunnitelman roolista johtuen kalastusalueen toiminta vaikuttaa merkittävästi siihen, miten kalastusmatkailua voidaan harjoittaa tietyllä alueella. Toki kalatalousalueen toiminnan vaikutuksia rajoittaa jossain määrin se, että kalastuslain 37 §:n mukaan kalataloussuunnitelma on hyväksytettävä ELY:llä. ELY voi hyväksyä suunnitelman vain, jos se on yhteensopiva valtakunnallisen kalavarojen hoitosuunnitelman kanssa, jossa taas todetaan, että kalastusmatkailuun ja kaupalliseen kalastukseen soveltuvista alueista olisi hyvä sopia yhdessä näiden elinkeinojen harjoittajien kanssa. Suunnitelmassa myös suositellaan kalatalousalueita laatimaan suunnitelmat niin salliviksi, että elinkeinoille jää tilaa. Tähän ei kuitenkaan velvoiteta, ja asia jätetään lopulta kalatalousalueiden harkintaan (Maa- ja metsätalousministeriö, 2018, s. 89). Kalatalousalueet voivat siis halutessaan vaikeuttaa kalastusmatkailua ja kaupallista kalastusta merkittävästi käyttö- ja hoitosuunnitelman avulla. Toisaalta ne voivat toimia myös näiden elinkeinojen mahdollistajina. Kaupallisen kalastuksen intressit on aikaisemmin huomioitu kalastusmatkailua enemmän poliittisessa päätöksenteossa (Salmi \& Salmi, 2010). Nähtäväksi jää, miten kaupallinen kalastus ja muut kalastuksen muodot huomioidaan käyttöja hoitosuunnitelmissa. Taulukossa 1 on esitetty eri kalastuksen tyyppeihin vaikuttavat lait, asetukset ja muu sääntely. 
Taulukko 1. Kalastuksen sääntely ja sääntelyn merkittävimmät vaikutukset kaupalliseen kalastukseen ja kalastusmatkailuun.

\begin{tabular}{lll} 
& KAUPALLINEN KALASTUS & KALASTUSMATKAILU \\
$\begin{array}{l}\text { Neuvoston asetus yhteisestä } \\
\text { kalastuspolitiikasta ja sen } \\
\text { nojalla annetut asetukset } \\
\text { (EU-sääntely) }\end{array}$ & $\begin{array}{l}\text { Jakaa jäsenvaltioille } \\
\text { kalastuskiintiöt, jotka jaetaan } \\
\text { kaupalliselle kalastukselle. }\end{array}$ & Ei vaikutusta. \\
\hline $\begin{array}{l}\text { Laki Euroopan unionin yhteisen } \\
\text { kalastuspolitiikan kansallisesta } \\
\text { täytäntöönpanosta } \\
\text { (EU-sääntely) }\end{array}$ & $\begin{array}{l}\text { Kansallinen viranomainen jakaa } \\
\text { lain perusteella EU-kiintiöt } \\
\text { kalastajille. Voi olla jakamatta } \\
\text { osaa kinntiöistä, jos katsoo } \\
\text { kestävyyden vaativan sitä. }\end{array}$ & Ei vaikutusta. \\
\hline $\begin{array}{l}\text { Kalastuslaki } \\
\text { (Kansallinen sääntely) }\end{array}$ & $\begin{array}{l}\text { Määrittää, kuka saa kalastaa } \\
\text { milläkin vesialueella ja millaisia } \\
\text { lupia kalastukseen tarvitaan. }\end{array}$ & $\begin{array}{l}\text { Määrittää, kuka saa kalastaa } \\
\text { milläkin vesialueella ja millaisia } \\
\text { lupia kalastukseen tarvitaan. }\end{array}$ \\
\hline $\begin{array}{l}\text { Kalastusasetus } \\
\text { (Kansallinen sääntely) }\end{array}$ & $\begin{array}{l}\text { Kieltää tiettyjä pyydyksiä ja } \\
\text { rauhoittaa tiettyjä kalalajeja. }\end{array}$ & $\begin{array}{l}\text { Kieltää tiettyiä pyydyksiä ja } \\
\text { rauhoittaa tiettyjä kalalajeja }\end{array}$ \\
\hline
\end{tabular}

\section{Kalastuksen sääntelyn tavoitteet ja siihen vaikuttavat intressit}

Kalastusmatkailun katsottiin lakia muutettaessa tuovan samanlaisia hyötyjä kuin tutkimuksissakin on havaittu. Kalastusmatkailun toiminnan helpottamiseen yhtenä perusteena oli se, että kalastusmatkailu tuottaa hyötyä syrjäisille alueille, missä muita töitä on tarjolla melko niukasti. Kalastusmatkailun sallimisen arvioitiinkin vaikuttavan myönteisesti työllisyyteen, matkailutuloihin ja aluekehitykseen (HE 135/2011 vp, s. 3). Kaupallista kalastusta helpotettaessa taas toimintaa tarkasteltiin koko arvoketjun näkökulmasta ilman alueellisia vaikutuksia (HE 192/2014 vp, s. 20). Kalastusmatkailua helpotettaessa vastakkaiset intressit olivat vesialueen haltijan omistusoikeus ja taloudellisen toiminnan edistäminen. Laajennettaessa oikeutta kalastusmatkailuun joudutaan rajoittamaan vesialueen haltijan yksinoikeutta vesialueen luonnonvaroihin.

Erityisen ongelmalliseksi yksinoikeuden rajoittaminen muodostuu omistusoikeuden suojan kannalta sellaisissa tilanteissa, joissa muiden toimijoiden käyttö rajoittaisi vesialueen omistajan kalavarojen käyttöä (PeVL 58/2014 vp - HE 192/2014 vp). Vesialueen omistajan kalavarojen käytöllä tarkoitetaan käytännössä kotitarvekalastusta. Kun aiemmin on säädetty muiden tahojen oikeudesta käyttää vesialuetta kalastukseen ilman omistajan suostumusta, on ehdottomana edellytyksenä tälle pidetty sitä, että omistajan kalastusoikeutta ei rajoiteta eli että kalakantoja voidaan kalastaa kestävästi siten, että omistajan mahdollisuudet saada kalaa eivät vähene (HE 192/2014 vp, s. 38-39). Toisaalta vapaa-ajankalastus tuskin kovin usein rajoittaa vesialueen omistajan mahdollisuutta käyttää kalavaroja, koska vapaa-ajankalastajilta kerätyillä maksuilla käytännössä rahoitetaan kalakantojen hoito (Markuksela, 2009, s. 47).

Toisena intressinä lainmuutoksissa on huomioitu rantojen omistajille toiminnasta aiheutuva häiriö. Kalastusmatkailun aiheuttamaa häiriötä ei pidetty merkittävänä, vaan se on lain- 
säätäjän näkemyksen mukaan hyvin pienimuotoista verrattuna muiden yleiskalastusoikeuksien käytöstä aiheutuvaan häiriöön (HE 135/2011 vp, s. 4). Yleiskalastusoikeuksien osalta häiriöt jäävät myös oletettavasti pieniksi, koska suomalaisessa kalastuskulttuurissa otetaan huomioon ympäristö ja toiset ihmiset sekä käyttäydytään vesillä hyväksyttävästi (Markuksela, 2009, s. 191193). Laajennettaessa kaupallisen kalastuksen mahdollisuuksia viranomaisluvan perusteella viranomainen velvoitettiin arvioimaan, aiheuttaisiko toiminta haittaa rantojen omistajille tai vesialueen muulle käytölle (HE 192/2014 vp, s. 38-39). Jos kalastusoikeuden haltijan kalastukselle tai vesistön muulle käytölle aiheutuu merkittävää haittaa, lupaa ei saa myöntää.

Lainsäätäjä on tulkinnut, että useimmissa tapauksissa kalastusmatkailu ei aiheuta kalakannoille ylimääräistä rasitetta verrattuna yleiskalastusoikeuksien käyttöön (HE 135/2011 vp, s. 3). Kaupallisen kalastuksen sallimista ilman kalastusoikeuden haltijan lupaa viranomaispäätöksellä laajennettiin vuonna 2015 uudella kalastuslailla. Tällöin tavoitteena oli hyödyntää paremmin vajaasti hyödynnettyjä kalakantoja (HE 192/2014 vp, s. 20). Tällöinkään kalastusmatkailua ja kaupallista kalastusta ei asetettu toisilleen vastakkaisiksi toiminnoiksi, vaan näitä punnittiin kalastusoikeuden haltijoiden oikeuksia vasten. Kalastusmatkailun osalta arvioitiin, paljonko se vaikuttaa kalastusoikeuden haltijan mahdollisuuksiin kalastaa itse, ja viranomaisen asettamia lupaehtoja eli mahdollisia kalastusrajoituksia punnittiin nimenomaan tätä taustaa vasten. (PeVL 8/2012 vp - HE 135/2011 vp.) Toisaalta molemmissa lakiesityksissä kalastusalueen haltijan oikeutta kalavaroihin rajoitettiin sillä perusteella, että näillä rajoituksilla voitaisiin edistää elinkeinonharjoittamisen mahdollisuuksia (HE 192/2014 vp, s. 103; HE 135/2011 vp, s. 3).

Kaupallisen kalastuksen edistämisessä pääasiallinen intressi näyttää olevan kalavarojen tehokkaampi käyttö ja sitä kautta kalastuselinkeinon edistäminen (HE 192/2014 vp, s. 20). Kalastusmatkailua säänneltäessä merkittävimpänä intressinä on ollut maaseudun ja rannikkoalueiden elinvoimaisuuden parantaminen, vaikka myös elinkeinon kehittäminen itsessään on huomioitu (HE 192/2014 vp, s. 41; HE 135/2011, vp s. 2-4). Vastakkaisena intressinä on ollut vesialueen haltijan kalastusoikeus, jota tähän mennessä on rajoitettu vain niiltä osin kuin se on ollut mahdollista vähentämättä vesialueen haltijan mahdollisuuksia kalastaa alueellaan (PeVL 58/2014 vp - HE 192/2014 vp). Vesialueen haltijan näkökulmasta kalastusmatkailu on huomattavasti perustellumpi toiminto, koska siinä vesialueen haltija saa tuottoja kalastuksen mahdollistamisesta ilman, että tuotot ovat riippuvaisia kalastetun kalan määrästä eli hänen kalastusoikeuttaan rajoittavasta tekijästä (Maa- ja metsätalousministeriö, 2018, s. 54). Näistä näkökulmista kalastusmatkailu vaikuttaisi olevan perustellumpi elinkeino rajoitettaessa alueen omistajan oikeuksia. Kalastusmatkailu ei nykyisellään juuri rajoita suojattua intressiä eli alueen omistajan kalastusmahdollisuuksia, ja tämän vuoksi kalastusmatkailulla tulisi olla selkeä etusija painotettaessa kaupallisen kalastuksen ja kalastusmatkailun välisiä intressejä.

\section{Keskustelu}

Aikaisemmassa kirjallisuudessa on katsottu, että kalastusmatkailu tuottaa kaupallista kalastusta enemmän arvoa sekä kalastettua kalaa kohden että aluetaloudellisesti (Cap Gemini Ernst \& Young, 2003; Kauppila \& Karjalainen, 2012). Tämä on otettu myös Suomessa jossain määrin ka- 
lastuksen sääntelyn lähtökohdaksi. Aluetaloudelliset vaikutukset ovat olleet perusteena edistää kalastusmatkailua. Suomessa vesialueen haltijan kalastusoikeus on ollut perinteisesti lähtökohtana kalastukselle. Tätä oikeutta on kuitenkin rajoitettu useita kertoja: ensin 1990-luvulla sallittaessa kalastus yleiskalastusoikeuksien nojalla, sitten sallittaessa vuonna 2011 kalastusmatkailu ja vuonna 2015 kaupallinen kalastus viranomaisluvalla. Kahta jälkimmäistä perusteltiin sillä, että kalaresurssit ovat nykyisen kalastusoikeusjärjestelmän vuoksi alihyödynnettyjä, ja niiden tehokkaampi hyödyntäminen voisi mahdollistaa sekä kaupallisen kalastuksen että kalastusmatkailun laajemman harjoittamisen ja tuottaa kalastusmatkailun kautta aluetaloudellisia hyötyjä.

Kansallisessa sääntelyssä on huomioitu myös kalastusten erilaiset tavat luoda arvoa. Kaupallisessa kalastuksessa taloudellisen arvon tuottaminen perustuu pyydetyn kalan määrään, jolloin kalastuksen määrä pyritään maksimoimaan ja kalan pyyntikustannukset minimoimaan (Hamilton-Hart \& Stringer, 2016; Kasulo \& Perrings, 2006). Tämä on usein johtanut liikakalastukseen, jota on pyritty hillitsemään sekä Euroopan unionin että kansallisella tasolla (Oksanen, 2011, s. 262). Suomessa kalastuspolitiikan ja kalastuslainsäädännön tavoitteena oli pitkään kalavarojen mahdollisimman tehokas kestävä käyttö (Mylly, 2007, s. 10). Tätä ei mainita enää nykyisessä kalastuslaissa tai sen esitöissä. Kalastuslakiin lisätyt helpotukset kalastusmatkailulle ja kaupalliselle kalastukselle perusteltiin kutenkin sillä, että kalastusoikeusjärjestelmä ei ole johtanut kalavarojen tehokkaaseen käyttöön, koska omistuksen hajanaisuuden takia kalastusmatkailua harjoittavien tahojen ja kaupallista kalastusta harjoittavien kalastajien on vaikea päästä sopimukseen vesialueiden omistajien kanssa.

Merialueilla vastaavaa ongelmaa ei ollut, koska vesialueet ovat pääosin valtion omistamia ja kalastusta säännellään niillä EU-sääntelyyn pohjautuvalla erityissääntelyllä, jolla pyritään varmistamaan kalavarojen käytön kestävyys ja kalastusoikeuksien tasapuolinen jako. Suurimpana haittana vaelluskaloille on nähty liikakalastus merellä, joka on vähentänyt kalastusmatkailussa saatavan saaliin määrää ja kokoa (Salmi \& Salmi, 2010). Kalastus merialueilla voi kuitenkin olla haitallista kalastusmatkailulle useilla tavoilla. Ensinnäkin liikakalastus merialueilla haittaa kalastusmatkailua rannikkoalueilla, ja kalasaaliit ovat uhattuina (Erkinaro ym., 2018). Tämän lisäksi vaelluskalojen kalastus meri- ja rannikkoalueilla haittaa kalastusta jokialueilla, erityisesti kalastusmatkailulle tärkeän lohen kalastusta. (Maa- ja metsätalousministeriö, 2018, s. 53).

Koska EU:n asettamat kalastuskiintiöt ovat jo nykyisin kestävän kalastuksen ylärajoilla, kansalliselta kalastuspolitiikalta vaaditaan aktiivista otetta, jotta kalastuksen eri muodot turvataan merialueilla tapahtuvalta liikakalastukselta (Oksanen, 2011, s. 262). Kansallisella tasolla onkin suojattu kalakantoja myös rauhoituksilla ja pyyntimitoilla, mutta sallittua kalastuksen määrää ei ole rajoitettu kestävälle tasolle. Koska EU-tason toimia ei välttämättä voida odottaa, valtion tulisi kalastuksen kestävyyden turvaamiseksi rajoittaa kaupallisille kalastajille merialueilla jaettavia kiintiöitä siten, että kestävän kalastuksen rajat eivät ylittyisi. Tämä palvelisi myös kaupallisen kalastuksen taloudellista hyötyä, koska se varmistaisi pitkän aikavälin kalasaaliin maksimoinnin (Conrad, 2011, s. 30-60). Se myös lisäisi koko kalastuksen taloudellista arvoa mahdollistaen enemmän arvoa luovan kalastusmatkailun harjoittamisen ja kaupallisen kalastuksen harjoittamisen kestävällä tavalla. 
Sisävesien kalakantoihin ei näytä liittyvän samanlaisia ongelmia, koska kalastus sisävesillä on katsottu kestävämmäksi ja kaupallisen kalastuksen mahdollisuuksia on jopa lisätty kalavarojen tehokkaan käytön mahdollistamiseksi. Vapaa-ajankalastus sisävesillä myös rahoittaa kalakantojen hoidon (Markuksela, 2009, s. 47).

Kalastusoikeussopimuksiin liittyviä ongelmia on ennustettu aiemmin. Ongelmien syy on, että transaktiokustannukset ja mahdollisuus ylihinnoitella kalastusoikeudet johtaa siihen, että kalastusoikeudet eivät jakaudu tehokkaasti (Mylly, 2007, s. 12). Mahdollisuus ylihinnoitella kalastusoikeudet johtuu siitä, että pienikin vesialue keskellä laajempaa aluetta saattaa estää koko alueen käyttämisen kalastukseen (HE 192/2014 vp, s. 38). Tämä otettiin lähtökohdaksi myös sallittaessa kalastusmatkailua ja kaupallista kalastusta viranomaisluvalla. Kalastusmatkailulle asetettiin kuitenkin rajoitus eli enintään kuusi henkilöä kalastusmatkailutapahtumaa kohden. Kaupallinen kalastus lisää huomattavasti enemmän kalavarojen käyttöä ja aiheuttaa sitä kautta haittaa vesialueen haltijalle (Salmi \& Salmi, 2010). Myös lainsäätäjä on tunnustanut tämän ja todennut useasti, että kalastusmatkailun aiheuttama haitta on verrannollinen lähinnä yleiskalastusoikeuksien käyttöön. Kun otetaan vielä huomioon lupa- ja valvontaviranomaisena toimivan ELY:n laajat mahdollisuudet asettaa erilaisia lupaehtoja kalavarojen käytön turvaamiseksi, ei lakiin asetettu kuuden kalastajan rajoitus vaikuta perustellulta.

Määtän (2011, s. 35) mukaan alueiden väliset erot puoltavat joustavaa lainsäädäntöä tarkkarajaisesti määritellyn sijaan. Tämän perusteella esitän väittämän, että kalastuslakiin otettu kuuden kalastajan enimmäisrajoitus ei vastaa sääntelyn tavoitteita, koska tällöin ei voida huomioida paikallisia olosuhteita niissä tilanteissa, joissa lupaa ei saada vesialueen haltijalta mutta joissa suuremmat ryhmät olisivat mahdollisia ja toiminnan kannattavuus saattaisi jopa vaatia sitä. Vesialueen pienempi kantokyky voidaan kuitenkin huomioida lupaehdoissa. Sääntelyn joustamattomuus aiheuttaa siis luultavasti menetettyä hyötyä maaseutu- ja rannikkoalueille, vaikka sääntelymuutoksilla pyrittiin pitkälti näiden alueiden elinvoiman edistämiseen. Vesialueiden haltijaa sääntelyn joustavuuden puute ei suojaa, koska tämän omistusoikeutta huomattavasti enemmän loukkaavaa kaupallista kalastusta säännellään kevyemmin. Maa- ja metsätalousministeriön (2018, s. 54) arviossa on katsottu, että vesialueen haltija saa suurimman hyödyn silloin, kun alueella harjoitetaan kalastusmatkailua kaupallisen kalastuksen sijaan.

\section{Johtopäätökset}

Tutkimuksen tavoitteena oli ensinnäkin selvittää, mitkä ovat keskeiset kalastusmatkailun tuottamaan taloudelliseen arvoon vaikuttavat tekijät ja miten nämä eroavat kaupallisen kalastuksen vastaavista. Kaupallisen kalastuksen tuottama arvo perustuu pitkälti kalan ravintoarvoon, ja kalastetun kalan arvo ja tuotto jakautuvat enimmäkseen jalostus- ja vähittäismyyntiketjuun. Kalaa pyritään kalastamaan mahdollisimman paljon ja samalla minimoimaan kalastetun kalan kustannukset. Tämä johtaa usein liikakalastukseen ja kalavarojen kestämättömään käyttöön, minkä vuoksi kaupallista kalastusta on jouduttu merkittävästi rajoittamaan.

Kalastusmatkailussa taloudellinen arvo kalaa kohden voi olla moninkymmenkertainen muihin kalastuksen muotoihin verrattuna. Kalan arvo ei perustu kalastetun kalan ravinto- 
arvoon vaan elämykseen ja virkistysarvoon, jota matkailija saa kalastuskokemuksesta. Tämän vuoksi kalastusmatkailun tuottama arvo ei ole suoraan riippuvainen kalastetun kalan määrästä. Kalastusmatkailun tuottama hyöty myös kohdistuu enemmän sille alueelle, jossa kalastus tapahtuu. Kalastusmatkailija käyttää merkittävästi rahaa majoitus- ja ravintolapalveluihin, millä on myönteisiä aluetaloudellisia vaikutuksia. Myös itse kalastusmatkailuun ja kalastusvarusteisiin käytetään rahaa. Edellä todetun perusteella voidaan todeta, että kalastusmatkailu tuottaa huomattavasti enemmän arvoa kalastettua kalaa kohden kuin muut kalastuksen muodot ja kalastusmatkailun tuottama arvo jää selkeämmin alueelle, kun taas kaupallisen kalastuksen arvo jakautuu jalostukseen ja vähittäismyyntiin.

Tutkimuksen toisena tavoitteena oli selvittää, miten sääntely vaikuttaa kalastusmatkailun ja sen kanssa mahdollisesti kilpailevan kaupallisen kalastuksen ja virkistyskalastuksen toiminnan mahdollisuuksiin. Nykytilanteessa merkittävin este kalastusmatkailulle ei ole resurssien jako kalastusmatkailun ja kaupallisen kalastuksen välillä vaan kalastusoikeuksien jako vesialueen omistajan ja elinkeinonharjoittajien välillä. Toki aikaisemmin liikalastus merellä on ollut uhka vaelluskaloihin perustuvalla kalastusmatkailulle, mutta nykyisin merikalastus on kohtuullisen kestävällä tasolla siihen kohdistuvien rajoitusten ja sääntelyiden ansiosta.

Lähtökohtaisesti kalastusoikeus kuuluu yksinomaan vesialueen haltijalle tai sille, joka on saanut häneltä kalastusoikeuden. Tätä yksinoikeutta rajoitetaan kuitenkin lainsäädännöllä. Viranomaiset voivat myöntää luvan kaupalliseen kalastukseen tai kalastusmatkailuun vesialueella, jos vesialueen haltijan lupaa ei saada. Edellytyksenä tälle on, että toiminta ei haittaa kalastusoikeuden ydinaluetta eli mahdollisuutta kalastaa. Toisena edellytyksenä luvalle on kalakantojen kestävyys. Perusteluna tälle poikkeukselle pidettiin elinkeinojen harjoittamisen helpottamista sekä erityisesti kalastusmatkailun tuottamia hyötyjä maaseuduille ja rannikkoseuduille. Lainsäädäntö rajoittaa enemmän kalastusmatkailua kuin kaupallista kalastusta, koska kalastusmatkailulle asetetaan tiukempia rajoituksia lupalainsäädännössä sen sijaan, että jätettäisiin rajoitukset viranomaisen harkittavaksi tapauskohtaisesti. Nykyinen sääntely suosii jossain määrin kaupallista kalastusta, koska ainakin lainsäädäntö asettaa vähemmän rajoituksia kaupalliselle kalastukselle toisen vesialueella viranomaisluvalla. Tämä on erikoista lainsäädännön tavoitteiden näkökulmasta, koska kalastusmatkailu haittaa vesialueen omistajan oikeuksia vähemmän kuin kaupallinen kalastus.

Lisäksi tavoitteena oli selvittää, miten sääntelyä voitaisiin kehittää kalastusmatkailua helpottavaan suuntaan. Johtopäätöksenä voidaan todeta, että jos kalastuksesta syntyvää arvoa haluttaisiin maksimoida, kalastusmatkailua tulisi helpottaa. Tämä voitaisiin toteuttaa laajentamalla viranomaisen harkintavaltaa lupa-asioissa myös kuutta kalastajaa suurempiin kalastusryhmiin. Tämä harkintavalta lisäisi todennäköisesti kalastusmatkailua. Jos lupaharkinta niin vaatii, tulisi kalastusmatkailu asettaa kaupallisen kalastuksen edelle, ja tästä etusijajärjestyksestä olisi säädettävä laissa. Tämän lisäksi kalastusmatkailua voitaisiin tukea epäsuorasti myöntämällä merialueilla vähemmän lupia sellaisten kalojen kalastukseen, jotka ovat tärkeitä kalastusmatkailussa. Tämä olisi myös kalakantojen kestävyyttä tukeva toimi, joka olisi sekä kansallisen että EU:n kalastuspolitiikan tavoitteiden mukaista. 


\section{Lähteet}

Aarnio, A. (2011). Luentoja lainopillisen tutkimuksen teoriasta. Helsingin yliopiston oikeustieteellinen tiedekunta.

Camară, G. \& Munteanu, M.-V. (2016). Exploitation of hunting and fishing tourism in Galați county, Romania. Present Environment and Sustainable Development, 10(2), 195-206. https://doi. org/10.1515/pesd-2016-0037

Cap Gemini Ernst \& Young. (2003). Vurdering av turistfiske som inntektskilde i Norge - hvilke inntekter gir turistfiske sammenlignet med yrkesfiske? Trondheim.

Conrad, J. M. (2000). Resource economics. Cambridge University Press.

Erkinaro, J., Heikinheimo, O., Jaala, E., Jokikokko, E., Keinänen, M., Koljonen, M.-L., ...Veneranta, L. (2018). Kalakantojen tila vuonna 2017 sekä ennuste vuosille 2018 ja 2019. (Luonnonvara- ja biotalouden tutkimus 36/2018.) Luonnonvarakeskus. Haettu osoitteesta http://urn.fi/URN:ISBN:978-952-326-604-9

Gurung, T. B. \& Thing, A. (2016). Fishing tourism can support fisher's livelihood and fish conservation in Nepal: A value chain analysis. Hydro Nepal: Journal of Water, Energy and Environment, 18, 55-60. https://doi.org/10.3126/hn.v18io.14647

Hamilton-Hart, N. \& Stringer, C. (2016). Upgrading and exploitation in the fishing industry: Contributions of value chain analysis. Marine Policy, 63, 166-171. https://doi.org/10.1016/j.marpol.2015.03.020

HE 135/2011 vp. Hallituksen esitys eduskunnalle laiksi kalastuslain muuttamisesta.

HE 192/2014 vp. Hallituksen esitys eduskunnalle kalastuslaiksi ja eräiksi siihen liittyviksi laeiksi.

Hänninen, J. \& Tonder, M. (2001). Matkailukalastuksen kehittäminen Saimaan Pihlajavedellä. (Kala- ja riistaraportteja, 240.) Riista- ja kalatalouden tutkimuslaitos.

Jacek, Z. \& Matczak, M. (2018). Role of maritime ports and shipping in the creation of the economic value of the sea areas. SHS Web of Conferences 58:01033.

Kasulo, V. \& Perrings, C. (2006). Fishing down the value chain: Biodiversity and access regimes in freshwater fisheries - the case of Malawi. Ecological Economics 59(1), 106-114. https://doi. org/10.1016/j.ecolecon.2005.09.029

Kauppila, P. \& Karjalainen, T. (2012). A process model to assess the regional economic impacts of fishing tourism: A case study in Northern Finland. Fisheries Research, 127-128, 88-97. https:// doi.org/10.1016/j.fishres.2012.05.004

Lee, L.-H. (2016). The relationship between visual satisfaction and water clarity and quality management in tourism fishing ports. Journal of Water Resource and Protection, 8, 787-796. https:// doi.org/10.4236/jwarp.2016.88064

Luonnonvarakeskus. (2018). Kokonaiskalantuotanto 2017. Haettu osoitteesta https://stat.luke.fi/ tilasto/7241

Luonnonvarakeskus. (2019). Raportti muikkukantojen tilasta 2017-2018. Haettu osoitteesta https:// www.luke.fi/wp-content/uploads/2018/07/Raportti-muikkukantojen-tilasta-2017-2018.pdf 
Maa- ja metsätalousministeriö. (2018). Kalavarojen käyttöja hoito: A.

Markuksela, V. (2009). Sitoutuneet vapaa-ajankalastajat harrastajina ja matkailijoina. Oulun yliopisto.

Markuksela, V. (2013). "Aisti kuin kala": Etnografia vetouistelun veljeskunnan kilpailukäytännöstä. Rovaniemi: Lapin yliopistokustannus.

Moksness, E. \& Gjøsæter, J. \& Lagaillarde, G. \& Mikkelsen, E., Moland Olsen, E., Sandersen, H. T. $\&$ Vølstad, J. H. (2011). Effects of fishing tourism in a coastal municipality: A case study from Risor, Norway. Ecology and Society 16(3), Article 11. https://doi.org/10.5751/ES-04290-160311

Mylly, T. (2007). Coase kohtaa kalastusrikosoikeuden - oikeustaloustiede. KKO 2006:70. Oikeustieto, $5 / 2007$.

Määttä, K. (2002). Oikeudellisen sääntelyn tutkimus - lastuja sääntelyteoriasta. Oikeus, 2/2012, $132-142$.

Määttä, K. (2016). Oikeustaloustieteen perusteet. Helsinki: Edita.

Määttä, K. (2011). Elinkeinotoiminnan sääntelystä Suomessa. Edilex.

Naji, M., Araba, A., Benabdellah, M., Dehhaoui, M. (2015). Governance and income in the Moroccan artisanal fishing sector: Analyzing the value chain. New Medit, 14(4), 11-18.

Neuvoston asetus yhteisestä kalastuspolitiikasta. Euroopan parlamentin ja neuvoston asetus (EU) N:o 1380/2013, annettu 11 päivänä joulukuuta 2013, yhteisestä kalastuspolitiikasta, neuvoston asetusten (EY) N:0 1954/2003 ja (EY) N:0 1224/2009 muuttamisesta sekä neuvoston asetusten (EY) N:o 2371/2002 ja (EY) N:0 639/2004 ja neuvoston päätöksen 2004/585/EY kumoamisesta OJ L 354, 28.12.2013).

Neuvoston kalakanta-asetus. Neuvoston asetus (EU) 2016/72, annettu 22 päivänä tammikuuta 2016, unionin vesillä ja unionin kalastusaluksiin tietyillä unionin ulkopuolisilla vesillä sovellettavien tiettyjen kalakantojen ja kalakantaryhmien kalastusmahdollisuuksien vahvistamisesta vuodeksi 2016 sekä asetuksen (EU) 2015/104 muuttamisesta OJ L 22, 28.1.2016. s. 1-165.

Oikeusministeriö. (2007). Säädösehdotusten vaikutusten arviointi: Ohjeet. (Oikeusministeriön julkaisu 2007:06.)

Oksanen, A. (2011). Kalakantojen kestävän käytön sääntely merialueilla - erityisesti kalastuskiintiöt ja niiden hallinta. Ympäristöpolitiikan ja-oikeuden vuosikirja 2011.

Padín, C., Lima, C. \& Pardellas, X. X. (2016). A market analysis for improving fishing tourism management in Galicia (Spain). Ocean and Coastal Management, 130, 172-178. https://doi. org/10.1016/j.ocecoaman.2016.06.007

Paukku, E. (2019). Luonnonvara- ja ympäristöpolitiikan eurooppalaistuminen: mahdollistaako EU:n valtiontukisääntely sinisen kasvun tukemisen Suomessa. Ympäristöpolitiikan ja -oikeuden vuosikirja 2019, 187-230.

Salmi, P. (2015). Constraints and opportunities for small-scale fishing livelihoods in a post-productivist coastal setting. Sociologia Ruralis, 55, 258-274. https://doi.org/10.1111/soru.12095 
Salmi, J. \& Salmi, P. (2010). Fishing tourism, biodiversity protection and regional politics in the River Tornionjoki, Finland. Fisheries Management and Ecology, 17(2), 192-198. https://doi. org/10.1111/j.1365-2400.2010.00736.x

Setälä, J., Harjunpää, H., Jaukkuri, M., Lehtonen, E., Långnabba, A., Mellanoura, J, ...Saarni, K. (2017). Kalastuksen olosuhdekatsaus 2016. Luonnonvarakeskus.

Stensland, S. (2010). Fishing rights and supply of salmon angling tourism in Mid-Norway. Scandinavian Journal of Hospitality and Tourism, 10, 207-230. https://doi.org/10.1080/15022250.2010.49 5483

Soppela, J. (2009). Lohenkalastajan monet kasvot: Vertaileva typologiatutkimus kalastusmatkailun vetovoimatekijöistä sekä kalastuksesta harrastuksena Lapin ja Kuolan niemimaan lohijoilla. Rovaniemi: Lapin yliopisto.

Tiitinen, J. (2007). Lohirengeistä kalastusmatkailuyrittäjiksi: Kalastusmatkailu Suomessa 1850-luvulta 2000-luvun vaihteeseen. Helsinki: Suomen Tiedeseura.

Vespestad, M. K., Lindberg, F. \& Mossberg, L. (2019). Value in tourist experiences: How nature-based experiential styles influence value in climbing. Tourist Studies, 19, 453-474. https:// doi.org/10.1177/1468797619837966

Vianna, G. M. S, Meekan, M. G, Pannell, D. J., Marsh, S. P. \& Meeuwig, J. J. (2012). Socio-economic value and community benefits from shark-diving tourism in Palau: A Sustainable use of reef shark populations. Biological Conservation 145, 267-277. https://doi.org/10.1016/j.biocon.2011.11.022 